This is a pre-print, author-produced version of a manuscript forthcoming in Historical Social Research / Historische Sozialforschung.

Pre-Print Version (November 2018)

\title{
„Formalizing the future: How central banks set out to govern expectations but ended up (en-)trapped in indicators“
}

\section{Please cite as:}

Walter, Timo. 2019. [Forthcoming] „Formalizing the future: How central banks set out to govern expectations but ended up (en-)trapped in indicators“. Historical Social Research 44 (2)

\subsection{5/osf.io/hrz7y}

Timo Walter

Universität Erfurt, Staatswissenschaftliche Fakultät

timo.walter@uni-erfurt.de

Universität Erfurt

Professur für Internationale Beziehungen

Postfach 900221

99105 Erfurt

\begin{abstract}
:
Modern 'inflation targeting' monetary policy has been one of the prototypes of future-oriented modes of social coordination which in recent years have captured the sociological imagination. Modern central banking is commonly presented as achieving greater efficacy by directly managing economic expectations, in particular when contrasted with the previous heavy-handed, "hydraulic" transmission of policy objectives through systems of economic aggregates. Such empirical claims are mirrored in the theoretical distinction drawn by sociologists between the openness and efficacy of future-oriented coordination of expectations, and the more rigid coordination achieved through formal organizing and formalization.

This paper uses the case of the US Federal Reserve's (Fed) transition to inflation targeting in the 1980s to show how the precision and flexibility of social coordination through expectations in fact relies on extensive formalization and rigid proceduralization. I show that the tightly coupled control relation on which inflation targeting rests is not possible without the constitutive exclusion of other modes of representing and intervening the economy achieved by this formalization. However, the price for the robust and precise reactivity that modern central banking has constructed between key indicators of inflation expectations and the interest rate set by monetary policy, is a comprehensive procedural dis-embedding of monetary policy from the structure of economic activities whose path into the future it is meant to govern.

The paper concludes that in order to better understand the conditions under which future-oriented modes of coordination fail or succeed, we need to study more closely the formalization of social relations on which they are founded.
\end{abstract}

\section{Keywords:}

central banks; monetary policy; expectations; futurity; economic coordination; indicators; inflation targeting 
Since the 1980s, central banks have proven themselves veritable masters at playing the game of the “politics of expectations” (Beckert 2016, 80). The "hydraulic”, Keynesian vision of monetary policy (which sought to exploit the trade-off between inflation and unemployment by managing aggregate demand) was gradually replaced by a novel regime focused on conducting the conduct of market actors, "whose activities propel the transmission mechanism of monetary policy” (Braun 2015, 369). Based on novel theoretical developments in macroeconomics such as in particular the Rational Expectations (RE) revolution (see Cesarano 1983), central banking today primarily relies on the "management of expectations" (Woodford 2003, 15ff.) for implementing monetary policy.

According to both practitioners and macroeconomic theory (Morris and Shin 2008; B. Friedman 2002; Woodford 2003), the (seemingly) remarkable efficiency of this novel regime of inflation targeting (Bernanke and Woodford 2006) is a result of its greater technical sophistication, compared to the rigidity and heavy-handedness of previous hydraulic implementation of monetary policy. Instead of influencing inflationary expectations indirectly through the manipulation of macroeconomic aggregates, modern monetary policy seeks to shape directly the structures of expectations of economic actors, which thus determines the effectiveness of policy. By focusing directly on the more pliable expectations mechanism, monetary policy thus can circumvent the disconnect between its policy measures and their ultimate target, inflation, that results from the lags and frictions as policy signals are transmitted through the system of economic aggregates. Following the famous "Lucas critique” of monetary policy (Lucas 1972, 1996), the key challenge for monetary policy thus consists in achieving credibility in terms of the predominant structure of (rational) expectations among economic actors: "if [monetary policy] is believable enough to shape (rational) expectations, it will work itself out like a self-fulfilling prophecy” (Mann 2018).

Since the rise to prominence of Rational Expectations thinking in the 1980s, central banks have set out to "govern the future” (Braun 2015) by deploying increasingly sophisticated “instruments of imagination” (Beckert 2016) such as forecasts, indicators and various forms of discursive framing as a means for shaping the expectations of economic actors. By providing a firm calculative "framing” (Braun 2015, 371) for (rational) expectations, such a future-oriented mode of coordination can be argued to achieve a more fine-grained and efficient conduct of conduct in the face of the fundamental openness and uncertainty of the future (cf. Beckert 2016, 51ff.), than the more heavy-handed and imprecise hydraulic monetary policy.

Social-scientific scholarship has predominantly tended to echo the claims made by practitioners and macroeconomic theory alike about the (technical) benefits of inflation targeting as a mode of monetary policy - although many remain critical of its affinities with neoliberalism (McNamara 2002, e.g.; Fernández-Albertos 2015). The idea of central bank communication shaping expectations has, however, captured the imagination of social scientists (Holmes 2014; Smart 2006; 
Abolafia 2010; Hall 2008). It has played into a widespread interest in questions of performativity, futurity and expectations in particular in fields such as economic anthropology and sociology. As a result, the image of central banks as key players in a process of jointly "narrating the future" (Holmes 2009, 386) has become very influential. Existing work on the social underpinnings of monetary policy has thus foregrounded how central banks deploy various instruments of imagination for the purpose of “organizing to produce decidability and actionability” (Power 2007, 5). This has yielded a vision of central banks creatively crafting "imagined futures” which become "performative to the extent that economic actors adjust their practices to fit the narrative" (Beckert 2016, 116) - thus allowing central banks to become dominant players in the "politics of expectations" through which the economy is increasingly governed.

More recent difficulties faced by inflation targeting, in particular the failure to "see" the 2008 financial crisis (Fligstein, Stuart Brundage, and Schultz 2017), and a return to more hydraulic policy tools under the label of “quantitative easing” (e.g. Braun 2016) have raised some hard questions about this storyline. Work on the communicative turn in monetary policy has neglected its structural preconditions, most significantly that a “communicative apparatus... [must first] disentangle and frame a space within which the formation and coordination of monetary expectations becomes possible in the first place” (Braun 2015, 372). Such reliance on formalizations and abstractions as a means to "enrol” other actors (Callon and Law 1982) in “centers of calculation” (Latour 1990) and thus shape their actions "at a distance” (Rose 1993) can in many cases improve the observability and control of the effectiveness of policy interventions (cf. Salais 2012, 57). However, formalization has always been a two-edged sword, in that it's effectiveness is based on extensive processes of bracketing and black-boxing.

Any “investment in form” (Thévenot 1984) necessarily involves a “rendering” (Thévenot 2009, 806) of the (joint) purpose of governing that entails trade-offs regarding whose perspectives on and which dimensions of a problem are included and represented, and thus made procedurally and operatively relevant for a given governmentality” (see Rose and Miller 1992). Questions about how and "when formality works" (Stinchcombe 2001) have arguably not received sufficient attention when it comes to monetary policy - neither among economists and practitioners, nor social scientists. This paper therefore seeks to “open the black box” (MacKenzie 2005) of the particular type of formality and abstraction that underlies inflation targeting. Its objective is to account for the considerable gap that has opened up in recent years between the narrow operative and technical efficiency of inflation targeting and its wider substantive effectiveness and rationality, particularly visible in its comprehensive neglect of financial (in-)stability (e.g. Fligstein, Stuart Brundage, and Schultz 2017; Golub, Kaya, and Reay 2014).

I take as a starting point for reflexion the case of the US Federal Reserve's (Fed) transition to inflation targeting, focusing in particular on the constitutive role of its 'Monetarist Experiment' 
under chairman Paul Volcker in the early 1980s. There, I trace the emergence of the specific formalization of monetary policy that made possible its remarkable, if narrow, operative and technical efficiency in conducting inflation expectations. I show how the formalization which makes possible this efficiency constitutively requires a disconnect of technical procedures from the activities it seeks to govern, resulting in limitations to its wider structural or social effectiveness typical of formal organizing (Power 1997; Meyer and Rowan 1977). The ability of inflation targeting to conduct expectations depends on a particular mode of futurity that would be impossible without comprehensive prior formalization and formal organizing. Rather than a simple forward extrapolation or projection which (performatively) coordinates actors and actions, inflation targeting involves a bidirectional form of futurity: in order to shape expectations of the future, this future is made a constitutive part of the present by making present operations indicators of the future to come. The future thus delineated on the basis of present indicators is constantly fed back into the present, reflexively reshaping present operations before the future projected ever materializes (Mallard 2017; Mallard and Lakoff 2011). Governing (the future through) expectations in this way thus does not directly require (or track) substantive changes in the macroeconomic aggregates it seeks to control, and which would correspond to the shifts in the structures of expectations it manufactures. As a result, rather than coordinating expectations and actions towards a jointly conceived future, this produces an operative proceduralization of "futurity". This proceduralization functions, in important respects, like a standard in that it vastly improves the reactivity (Espeland and Sauder 2007) of the actors and expectations linked by it, thus allowing for efficient fine-tuning within the frame of abstraction. At the same time, much like other forms of standardization, this formalization significantly reduces the ability of policy procedures based on it to operatively capture and deal with the substantive spectrum of the phenomenon or policy problem it is meant to govern (Thévenot 2009, 806; see also Salais 2012, 57; Diaz-Bone 2016, 55). 
Formal organization and the process of “organizing” as such (Weick, Sutcliffe, and Obstfeld 2005) in modern societies are characterized by a constant tension between the durability achieved by typification, abstraction and formalization on the one hand, and the various forms of informality in which formality is embedded and which it seeks to govern (see Stinchcombe 2001; Kallinikos 2004). Formality and abstraction are the precondition for the "instruments of imagination" such as formal theories, devices, or forecasts (Beckert 2016, 217ff.) by which joint social purpose(s) can be represented, imagined and re-embedded in situated action (see Hasselbladh and Kallinikos 2000; Stinchcombe 2001, 18-54).

In contrast, recent (sociological) scholarship on expectations and futurity as a distinct mode of social coordination (e.g. Beckert 2016; Mische 2009) has tended to present this as a phenomenon distinct from, in particular, the formalizations and abstractions on which research on the calculative foundations of economic dynamics has focused (e.g. Callon and Muniesa 2005; MacKenzie 2006). Given the fundamental uncertainty of the future, so the argument goes, the coordination of expectations necessarily relies on an element of “imagination” (cf. Beckert 2016, 51ff.), countervailing the iron cage of formally organized social action.

However, as David Stark has pointed out, uncertainty is not truly a property of the future per se, nor does it result from the boundedness of (subjective) rationality and the inability to know an unknowable future (Stark 2009, 14). Rather, it results from the dissonance between distinct "orders of worth" which prevents the delineation of explicit means-ends relationship by which joint social purpose is operationalized. Uncertainty thus means simply an absence of the conception and development of technologies of intervening by which the ends in terms of which they have become assembled can be realized (on organizing as a combination of “representing and intervening”, see Hacking 1983; Kallinikos, Hasselbladh, and Marton 2013; Habermas 1973; Rose and Miller 1992; Stinchcombe 2001). Successful coordination (of, and through expectations) thus requires effective formalization(s) in order to create joint frames that can link the "situations" in terms of which actors' calculations and expectations are defined (Stark 2009, 14). Uncertainty, then, is a property of situations in which agents find themselves, resulting from the indeterminacy of such joint situations (ibid.). Formalizations, in turn, "are engines for turning situations into calculative problems... [they] can be considered as social technologies to transform uncertainty into risk" (Stark 2009, 15).

If coordination is to be effective across multiple actors and contexts, it cannot escape the need for abstractions and representations which "function as instruments for the construction of imagined futures” (Beckert 2016, 89). Formalization, understood as “abstractions that govern” (Stinchcombe 2001, 43), makes possible to “organize alignment” (Suchman 2000) and thus improves the (technical) efficacy of coordination, while reducing cognitive load (Thévenot 2001b; 
Stinchcombe 2001, 18-54). Such effectiveness, however, requires first that alignment is achieved between conceptualizations of (the joint) purpose(s) of the activities to be governed

("governmentality”), formal ways of representing this field of activities which allow for identifying and delineating means-ends relations ("programmes"), and the "technologies" and devices meant to conduct the activities in question accordingly (Rose and Miller 1992; Thévenot 2001a; Stinchcombe 2001, 18-54). Indeed, this is precisely what modern monetary policy seeks to achieve: it “disentangles and frames a space within which the formation and coordination of monetary expectations becomes possible in the first place” (Braun 2015, 372) in order to better attune macroeconomic expectations to its policy interventions and make their meaning "discernable from the standpoint of situated subjects” (Holmes 2014, 25).

To achieve such an effective "pragmatic regime governing the engagement with the world" (Thévenot 2001a), it is necessary to make an investment in form (Thévenot 1984) which can effectively coordinate the substance of the (informal) practices in which its abstractions are embedded and which it is meant to govern (Stinchcombe 2001, 18-54). It is precisely in abstracting and commensurating different perspectives and situations ('substance') through a common form that frictions may occur, and foment pathologies of organizing:

"The justifiable engagement with a plurality of orders of worth integrated through compromise risks being destroyed by standardization, for the reasons this analysis has made clear. The level of worth geared towards the common good gets reduced to functional properties, measurable according to the engagement with a plan. Evaluation is restricted to the objective of the plan, rather than the rendering of a wider characterization of the common good” (Thévenot 2009, 806; see also Salais 2012, 57; Diaz-Bone 2016, 55).

When formalizations and / or formal organization fail to align with the substance of the (informal) activities to be governed, they can become merely "ritualistic" (Power 1997) performances, and continue as a "myth and ceremony" (Meyer and Rowan 1977) of formal rationality despite their increasing ineffectiveness for the actual purposes of social coordination.

Existing research on how central banks govern through expectations and futurity, but also the sociological literature on this mode of governing in general, has tended to downplay the problem of the adequacy (Stinchcombe 2001, 21ff.) of the formalization(s) underlying the formation and coordination of expectations. Holmes (2014) summarizes the conventional wisdom when he suggests that, unlike hydraulic and mechanical central banking, modern monetary policy proves more effective as it better manages to take into account, address descriptively and thus more effectively coordinate actors' expectations. In creating a shared frame through communicative practice which can better integrate contextual and situational knowledge, modern central banking governs through

"agile constructions of linguistic scenarios that are susceptible to continuous modification and elaboration... Expectations are alive in this economic scence and open to refinement and modification going forward. Unprecedented circumstances can be addressed 
descriptively, new ideas and new metaphors can be generated, and contestation can be treated as inherent at every level in this communicative field“" (ibid. 25).

Even contributions that explicitly concede that processes of framing expectations necessarily must bracket some facets of (social) reality and thus involve a loss of information (e.g. Braun 2015) have tended to give analytical priority to what Stinchcombe $(2001,10)$ calls the communicability of formalization(s), that is the question of how "an abstraction system of formality then [is] transmissible and correctly interpretable by the people who do the activity” (ibid.).

While there is nothing per se wrong with this focus, it severely undercuts our ability to understand how and why governing the future by imagination and expectations (sometimes) fails. As the (vast) literature(s) on the pathologies of formal organizations demonstrate, the ability of formalities to circulate and command (sometimes ritualistic) obedience from various actors is separate from the question of the adequacy of form to substance. This means that "in describing variations in abstraction systems that make them more or less effective at a given time, we need to describe what makes them accurate, economical, sufficient and of wide scope” (Stinchcombe 2001, 20). As future-oriented modes of governing expectations also (sometimes quite heavily) rely on various forms of abstractions and formalization as instruments of imagination (Beckert 2016, 21768), this suggests the need for a more cautious evaluation of the form of modern inflation targeting monetary policy than so far has been provided both by practitioners and macroeconomics, as well as their social-scientific observers.

In order to understand the sources of the (apparent) effectiveness of inflation targeting as well as of its pathologies, we thus need to examine the trade-off between its enormous effectiveness in terms of communicability (Stinchcombe 2001, 30ff.) on the one hand, and its adequacy on the other. Adequacy, succinctly put, involves "the accuracy of the abstractions, cognitive economy so the abstractions are easy to work with, sufficient to represent all the causes of all the relevant effects, and wide enough in scope so that it covers most of the situations in the ear of life it is supposed to govern” (Stinchcombe 2001, 10). In particular, there is one dimension that is particularly salient with regard to how inflation targeting monetary policy organizes alignment (or fails to do so): namely, the problem of adequation (Mann 2018, 12) of formalized representation with the activities to be governed. By adequation, I refer to the fact that a formalization "admits reality, but speaks only to those aspects that are articulable via its formal language” (ibid.). For an investment in form to provide a durable and robust means of governing the social, it is necessary that the ways in which it is related to the activities to be conducted by technologies of intervening do not conflict with the internal coherence and rules of manipulation of the formalization(s) (Mann 2018; Stinchcombe 2001, 57ff.).

Only if we understand how this is achieved are we also in a position to fully appreciate the possible sources of pathologies that result from such formalization(s). How does the mode of 
futurity and expectations management characteristic of modern inflation targeting relate to the field of activities it seeks to govern, then? This is the question we will first need to answer. 


\subsection{Formalizing monetary policy: how the Fed made inflation a 'technical' problem}

Since the 1980s, central banks around the world, following in many respects by the experience of the Federal Reserve, have abandoned (Keynesian and Monetarist) hydraulic monetary policy in favor of what later became known as inflation-targeting (Bernanke and Mishkin 1997). This label designates a bundle of changes in the operative implementation and conceptual representation of monetary policy that have developed concurrently in industrialized economies over the 1980s and 1990s. Retrospective accounts, as so often, portray this evolution in rather Whiggish terms, as a natural progression towards technically more sophisticated and effective conceptions and methods of monetary policy - an image that still reverberates through contemporary accounts of this transition. From the perspective developed here, a different question appears more salient: if we understand monetary policy as based on particular constitutive formalization(s) in the sense developed above, how (and why) precisely did these change? And how did this enable central banks, specifically the Fed, to claim to have discovered a more efficacious form of monetary policy? In order to answer this question, of course, it is first necessary to develop a diagnosis of the challenges and struggles the Fed faced in the run-up to this redefinition of monetary policy.

The characterization of pre-1980s monetary policy as "hydraulic" or mechanical is closely linked to the transition from static and sequential towards dynamic, inter-temporal general equilibrium theorizing driven, in large part, by the RE revolution's transformation of the mathematical formalism of macroeconomics. Hydraulic monetary policy was based on the immensely influential IS-LM curve (see Young and Zilberfarb 2000 for the constitutive role of ISLM for macroeconomics before RE), which allowed for a systematic and coherent depiction of how the supply of money (and its cost, i.e. the interest rate) would affect overall economic activity and thus monetary policy’s target variables (such as investment, employment) (see Mann 2018). However, the hydraulic influencing of macroeconomic variables through varying the price and supply of money depends on the existence of institutional rigidities, or "pockets of structure” (MacKenzie 2017, 174), which are not fully attuned to what later became called 'Rational' Expectations. At least some agents needed to not have a full grasp of the systemic, inter-temporal implications of varying the money supply so that they would mistake purely “monetary" impulses for real economic signals and change their behavior accordingly (cf. the critique by Lucas 1972). Without such pockets of structure whose constitutive structure of expectations was incongruent with the "true model" according to economic theory, hydraulic impulses would simply crepitate (or have unintended side-effects). As the famous Lucas Critique argued, in the presence of RE such monetary impulses would be neutral with regard to real economic activity: economic actors would simply and correctly anticipate that they would solely affect the price level and produce inflation, and fail to adjust their own behavior so as to produce any "real” economic effects. Conversely, 
given RE the true model of the economy held by economic actors would provide a frame for conducting their expectations directly.

Conventional wisdom portrays the dependence on rigidity and thus not-fully-rational expectations as the reason why hydraulic monetary policy was less efficacious than "modern" monetary policy in controlling inflation. However, on closer inspection, there remains considerable ambiguity as to whether it really was less effective in influencing inflation, in technical terms (Orphanides 2002, 2003), once political preferences are taken into account. From the perspective developed here, rather than assume a continuous, clearly delineable phenomenon of 'inflation' that could be controlled more or less effectively in technical terms, it is more instructive to ask how the formalization of inflation evolved, and how this affects the possibilities for governing it as a technical problem.

Retrospective accounts of the travails of monetary policy leading up to the 1980s “monetarist revolution” commonly diagnose a lack of decisiveness in combating inflation, stemming from two interrelated and mutually reinforcing factors: a lack of political will to firmly lean in against inflationary developments, aggravated by the heavy-handedness of procedures relying on institutional rigidities for the implementation of anti-inflationary measures. Over the course of the 1960s and 1970s, the technical deficiencies that resulted from these twinned factors became designated as interest rate smoothing and a resultant base drift. According to its critics, fear of political repercussions prevented the Fed from moving the interest rate sufficiently strongly and anti-cyclically (especially in booms) to control inflation, with the resultant lags generally reinforcing subsequent cyclical countermovements and allowing the monetary base (thought to be directly correlated with inflation) to grow in an uncontrolled fashion (Axilrod and Lindsey 1981; Meltzer 1991, 39; 43).

At the same time, practitioners and (expert) observers at the time also commonly discussed this as a predominantly technical problem, namely of getting the timing and magnitudes of policy interventions right in order to steer inflation and the business cycle smoothly, effectively and reliably. With Monetarist arguments gaining ground which saw the effectiveness of hydraulic stimulation of economic activity by "cheap money” as dependent on adaptive expectations (see M. Friedman 1968), expert debates in monetary policy came to focus on the technical problems of improving the timeliness and reducing the ambiguity of its policy interventions - in other words, on improving their communicability (see above).

These concerns led to an intense preoccupation with the adequation of monetary policy with the activities to be governed - that is, with how one could achieve a coherent formalization of the target domain (economic activities responsible for inflation), allowing for delineating clear-cut operational mechanisms that could robustly be triggered by reliable technologies of implementation. These debates, which extended over most of the 1970s, became known as the so-called Instrument- 
Target Problem (Bindseil 2004, 29ff.; Poole 1970). In a highly technical jargon, the InstrumentTarget Problem revolved around the endogeneity problems facing monetary policy due to the lags observed between operative and target variables, and the resulting instabilities of the functional relations between variables. In time, this led to a fundamental questioning of the operative ontology of monetary policy, that is, by what causal sequences monetary policy was actually (to be) transmitted - and which among the proliferating variables and macroeconomic categories were operative, intermediate or ultimate target variables.

Whereas the retrospective, Whiggish reading of this episode depicts it as a lack of political resolution coupled to 'faulty' macroeconomic theory, a focus on the evolution of formalization(s) draws attention to the processes by which the very phenomenon of inflation became represented in ways that allowed for novel technical solutions to be delineated and operationalized. Indeed, the very debates surrounding the Instrument-Target Problem are best understood, from the perspective adopted here, as an attempt at radical functional simplification, "the demarcation of an operational domain within which the complexity of the world is reconstructed as a simplified set of tight causeand-effect coupling” (Kallinikos 2014, 9). In this perspective, achieving ‘technical’ efficiency is possible only on the basis of a prior process of formalization which allows for insulating robust means-ends technical control relations from interference by other factors (see Kallinikos 2006, 32ff.).

As we saw above, the formalization of social practice requires that technologies of intervening are aligned with how a social good is represented in unambiguous and standardized terms, so that it becomes possible to coherently (and thus rationally) act in its pursuit through robust means-ends-relations as delineated by the representation. The Fed's monetary policy pre-1980s arguably lacked many of the properties that make formalization, and the practices it instructs, “efficient” in a narrow technical sense. Building on Offe’s (2006) arguments on how the "structural problems of the capitalist (welfare) state” over the course of the 1960s and 1970s had ushered into a configuration in which competing social priorities' struggle for resources put strains on the state apparatus, Krippner (2011) has shown how the Fed struggled to find a way to extricate itself and the conduct of monetary policy from political contestation.

While existing accounts of the Great Inflation of the "long 1970s" (from the mid-1960s to the early 1980s) identify political pressures as a key catalyst, the problem was not simply that monetary policy was directly implicated in the political struggles at the time, as Krippner, like many others, argues. Rather, monetary policy as a pragmatic regime had integrated competing accounts of worth, and conceptions and operationalizations of how inflation could be controlled, into a rather ambiguous and heterogeneous formalization and proceduralization of monetary policy. Different theoretical conceptions of the causal mechanism(s) driving inflation co-existed uneasily within its operative paradigm. Most famously, the so-called notion of “cost-push inflation” led the Fed into 
various attempts to target the credit extended to particular economic sectors considered to be driving general inflation, and into attempts to control wage dynamics. The real bills doctrine (see Glasner 1992) with its notion that productive credit could never be inflationary long persisted within the Fed, so that targeting free reserves (reserves not backing productive credit) was seen as a way to combat speculative pressures that could lead to asset and, through it, generalized inflation. Such partially incoherent substantive theories of inflation and the operative mechanisms they implied uneasily coexisted within the Fed's monetary policy. Its multifaceted conception of inflation also entailed a complex apparatus of technologies such as regulations of interest rates, relative (credit) prices and the allocation of money to different sectors of the economy (Konings 2011, 106ff.). Through this, monetary policy became drawn into and contested over an entire spectrum of competing accounts of social worth - whether to fund schools or missiles, homeownership or poor relief (with a little artistic license).

While this did not necessarily undermine the Fed's ability to be effective, it greatly undermined its technical efficiency, the "dissonance” (Stark 2009) in introduced into monetary policy procedures greatly facilitated political contestation as it disrupted the links between particular policy measures and a recognizable purpose into which they would cohere. From the point of view of its (mainly Monetarist, at the time) critics as well as today's inflation targeting regime, all of this constituted at worst a pathological interference in technically efficacious inflation control - and at best a confounding of what today are seen as distinct and (sometimes) conflicting policy objectives of price stability and financial stability. From the point of view defended here, however, it constitutes a different formalization of monetary policy - one that experienced difficulties due to its heterogeneous operationalization of inflation and the ambiguity of its technical implementation. At the same time, it remained in many ways more open and thus more adequate to inflation as a multifaceted phenomenon that affects many constituencies in different ways (see Carruthers and Babb 1996), and included a greater diversity of possible causal mechanisms and (macro-economic) situations than the regime that followed it.

However, under the combined influence of political contestation, the difficulties of developing a clear-cut, robust and unambiguous technical procedure for combating inflation, and the rise to prominence in expert cycles of an expectations theory of inflation, the Fed came to focus on the problem of the communicability of its policy measures. As a consequence, it ended up developing a functional simplification that undisputedly excels at making the intended meaning of policies decipherable for economic actors. However, this new formalization also came with drawbacks of its own: its core procedures ended up bracketing many of the causal interactions and sequences among present-time aggregate variables by which pre-1980s monetary policy had traced the transmission and effectiveness of its policy measures. Instead, the "effectiveness” of monetary policy afterwards came to be defined in terms of an implementation mechanism that is based on the 
reactivity of abstract (and indirect) indicators of expectations about the future to one particular operative policy variable, the short-term interest rate. 


\subsection{Proceduralizing and encasing monetary policy - how the Fed created the operative}

\section{bases for "governing the future":}

The contours of the re-formalization and functional simplification of monetary policy that ushered into inflation targeting are so naturalized today that they have become an unquestioned measure of the technical sophistication and efficacy of past monetary policy as well.

Contemporary (post-1990s) thinking on monetary policy has taken the habit of treating questions of its implementation as purely technical problems that can be discussed, refined and improved upon quite separately from the issue of how the policy impulses sent are transmitted through their target domain, the (macro-)economy. Bindseil, in his highly influential treatise of monetary policy implementation argues that questions of what he calls monetary policy strategy (i.e. how the manipulation of its operative target, the (short-term) interest rate affects the context of macroeconomic variables) are entirely irrelevant to its operative implementation (Bindseil 2004, 3). In line with the postulates of RE thinking about monetary policy (to which we will return shortly below), he goes so far as to suggest that it is precisely the lack of this distinction which prevented “Old” (pre-1990s) monetary policy from reaching the (allegedly) greater technical sophistication and efficacy of its “New” successor (Bindseil 2004, 234-254).

Instead of taking the undisputedly greater technical coherence and sophistication (especially on the side of implementation) of contemporary monetary policy as the cause for the Great Moderation (Bernanke 2004) of inflation rates since the late 1980s, let us ask what investment(s) in form made this possible in the first place. What is it that monetary policy is doing so much more efficaciously due to its re-formalization since the 1980s - and what had to be excluded and bracketed from its operative procedures to achieve this greater degree of technical mastery? Separating strategy and transmission from the procedures of implementation precisely cuts off the question I want to ask: namely, what changes in the formalization of monetary policy made possible this seemingly efficacious and robust alignment between its formal representation ("strategy") and the operative technologies of implementation? And how is this alignment instrumental for stabilizing a target domain in terms of which the impact of manipulating certain variables becomes procedurally measurable and observable?

As we have seen, the alignment and adequation of the formal (symbolic or technological) representation of a target domain with the ways in which the relations thus abstracted and represented are made manipulable by technologies ultimately determines monetary policy’s (technical) efficiency and effectiveness. Efficacy thus depends on the continued existence of the alignment of technologies and formalizations that constitutes this calculative space. What is more, the very criteria for and observability of what efficacy means are bound up inextricably with the calculative space set up by the alignment in the first place. 
Over the course of the $20^{\text {th }}$ century, monetary policy, like many other social fields (Desrosières 2013), has been undergoing a process of social objectivation as a result of the increasing formalization of economics and its quantificatory strategies (e.g. Backhouse 1995; Mirowski 1989, 2002; Hoover 2001). In particular the Neo-Classical Synthesis (Blanchard 2008) of Keynes's ideas with (static) general equilibrium theory had produced a resolutely systemic way of thinking about inflation and monetary policy. In particular the "workhorse” IS-LM model (Hicks 1937; see also Darity and Young 1995) had gone a long way in narrowing conceptions of inflation to the concept of the general price level within a formal general equilibrium vision of the economy. In doing so, it had laid the foundation for its later Monetarist reformulation which made the general price level, and thus inflation, a (synchronous) function of present expectations about the (fictive) future rather than of the sequential dynamics amongst (present) macroeconomic variables unfolding (diachronically) into an actual future (see M. Friedman 1968; see also Dimand 2007). By operationalizing futurity in terms of indicators formed by present-time feedback loops to shifting visions of the future, central banks thus make a "constitutive” use (Mallard 2017) of the future in the present. Before we can fully unfold the problematic implications of this mode of futurity, however, it is necessary to throw some light on the mechanical changes inside the black box of monetary policy that occurred in this period.

In re-framing inflation as a function of expectations, Monetarism provided the conceptual foundations for the theoretical and operative separation of implementation and transmission characteristic of modern monetary policy. Before RE macroeconomics, transmission was conceived of as occurring sequentially between aggregate macroeconomic variables related formally through the static, (theoretically) simultaneous equations of the IS-LM world. Afterwards, it began to be conceived of (theoretically and operatively) as passing through a signaling game influencing expectations rather than "real” macroeconomic aggregate variables (directly). Instead of having to worry about the adequacy of this formalization in terms of its scope (full spectrum of different actors’ situative calculations related to inflation) and sufficiency (in capturing all relevant mechanisms affecting inflation), RE economics provided the justification for focusing mainly on its cognitive economy and communicability (see Stinchcombe 2001, 18-54). To understand why this functional simplification worked in practice, we need to have a closer look at how monetary policy managed to abstract and disentangle itself operatively from the multiple "accounts of worth" which it had still incorporated well into the 1970s.

There is no doubt that numerous political and tactical consideration influenced the Fed's maneuvering in particular over the early 1980s, as is Krippner’s (Krippner 2011, 106-37) argument. However, the overriding operative and technical concerns were with the persistent problems of the lags arising before manipulations of instrument variables took their effects on target and ultimate policy variables (see above). As a result, the Fed sought to devise a system of policy 
implementation which could convey its policy stance more precisely and directly to markets than the often confusing signals that resulted from the lags arising from the complex system of relations between the macroeconomic aggregates manipulated by monetary policy. The terminology as well as debates surrounding this new system remained ambiguous for several years after: initially, the new system was marketed as a more efficient way of shaping the path of the money supply (not least to counter the public influence of Monetarist thinking in those years, but also within the Fed's own ranks). To this end, the Fed would estimate required reserves (base money supply), provide part of it directly through open-market operations, and let markets borrow the shortfall at the discount window at a higher cost. In this way, the Fed avoided the need to know expected money supply beforehand in order to match it by its actual supply of reserves. It also managed to avoid the disruptions that could result from a mismatch, due to the heterogeneity of expectations caused by the lagged interactions between market actors and the Fed. Instead, it would receive real-time feedback on this mismatch, depending on how much markets borrowed at the discount window over and above the initial provision of reserves. This allowed for a swift adjustment of the policy signal, while the market in turn would receive feedback about the Fed's evaluation of its own calculations. Often interpreted simply as a form of neoliberal "market-based” governance, this mechanism allowed for representing market expectations - it allowed the market to "show through" rather than overwrite the price-indicator for market expectations with a price driven mainly by the Fed's actions themselves (Krippner, 2011, p. 121ff.). This system thus presaged the framework and distinctive concern for fine-tuning control over the (short-term) interest rate characteristic of inflationtargeting.

In theory, markets would learn to interpret easing and hardening of the policy stance in numerical terms (today, we are all familiar with central bank's adjustment of policy rates in terms of “basis points”, i.e. usually quarters of one percent) and translate it into a rate for guiding their own credit-money expansion. However, the operative framework remained tied to the money supply as the ultimate target variable - which constituted its key weakness as the relation between the interest rate and the money supply suffered the same problem of lags and resultant volatilities as other control relations had before. In practice, markets at first failed to read Fed policy effectively (Cukierman and Meltzer 1986, 69; Feinman and Poole 1989), resulting in precisely the types of overshoots and credit crunches the Fed had sought to avoid by this mechanism (Meltzer 1991, 40; Rosenblum and Strongin 1983). On the positive side, though, the credit crunches and extremely high interest rates that resulted from this served the Fed as "credibility tests", which established its credentials as being tough on inflation (Goodfriend 2007, 51).

What is crucial about this new system from the perspective developed here is less the operational detail per se, nor the fact that (as any framing) it disentangles calculative processes and thereby necessarily involves a loss of information (see Braun 2015). Rather, the key issue is how 
this novel operative procedure disentangles monetary policy implementation: by tying (the control of) inflation directly to expectations and their manipulation, rather than indirectly through the manipulation of various macroeconomic aggregate variables. While both practitioners and macroeconomists still speak about (and reflect on) monetary policy in the idiom of (much the same) macroeconomic categories, operatively these categories have ceased to form a constitutive part of the transmission mechanism ${ }^{1}$, which now passes (exclusively) through the functional relation between the short-term interest rate and market expectations, and the signaling game made possible by it.

The problem of transmission thus becomes one of credibility, whose rise to prominence as one of the most widely debated concepts and issues regarding monetary policy is anything but accidental. In a RE world, transmission depends not on sequential causal transmission channels, but rather on credibility in terms of the structures of expectations of the (much-maligned) “representative agent” (Kirman 1992). A credible policy signal will, "if it is believable enough to shape (rational) expectations... work itself out like a self-fulfilling prophecy” (Mann 2018, 18), and trigger the shifts in macroeconomic variables concordant with the intended policy outcome(s). Redefining the control of inflation as an issue of credibility thus turned policy implementation into an issue of the communicability of the policy stance, whose technical efficiency manifested itself in how smoothly it could influence expectations about inflation. Additionally, credibility was also linked to the widely debated problem of time inconsistency (the possibility to take decisions that benefit some group but leave everyone worse off because there are means to postpone those costs in the future) endemic to monetary policy. Controlling inflation could thus be understood as a onedimensional communication problem, namely of signaling a stable inter-temporal commitment to low inflation (quite unlike the multi-dimensional conception of inflation that had prevailed before).

As the Fed quickly discovered, establishing a (direct) functional relationship between the short-term interest rate and inflation through the "black box" (MacKenzie 2005) of expectations achieved a number of extremely useful things. For one thing, it cut out the middlemen of (lagged) variables; like any effective technologization, it created a stringent "functional simplification" that significantly reduced interferences in the operative control relation. In addition, it vastly reduced the potential for policy contestation, as it allowed the Fed to claim that "the market” was actually responsible for economic outcomes, while itself it was only setting the short-term rate and not (actively) influencing economic activity (Krippner 2011, 116ff.). And finally, in disentangling this novel control relation, the Fed effectively installed a device through which it could pursue greater technical refinement and efficacy, while bracketing the larger question of the substantive effectiveness of its procedures in terms of a wider conception of inflation as an entanglement of

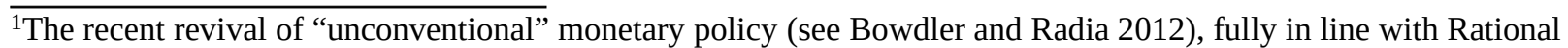
Expectations Economics, views these as a temporary necessity for restoring the transparency of the General Equilibrium after an (unusually large) "exogenous shock”, and thus as not requiring a rethinking of the normal problems of monetary policy implementation.
} 
multiple and heterogeneous economic processes. Economic theory provided the necessary justification for this narrowing of focus on implementation, by suggesting transmission was secured by the existence of RE.

However, the formalization and proceduralization achieved by the Fed's early Monetarist Experiment initially had some downsides. As long as it formally remained tied to a Monetarist rationale or programme aimed at better control of the money supply, the high reactivity it achieved produced highly volatile responses to the Fed's policy interventions, inducing severe recessions and credit crunches. However, this disadvantage turned out to be a blessing in disguise: the recessions induced not only helped structurally break inflation, but they pushed the Fed to further reformalize and simplify its novel proceduralization in a way that made the degree of reactivity the main measure and standard of its effectiveness. Reactivity of expectations thus came to be seen as evidence of a central banks' ability to control inflation expectations, and thus to govern (through) the future. But, how much "future" is there in modern inflation targeting really? In order to understand why a governance mechanism that was meant to improve control over future outcomes paradoxically has ended up quite thoroughly decoupled from the future it allegedly operatively shapes and controls, a little conceptual discussion is necessary first.

In a banal sense, every action and expectation is future-oriented (Tavory and Eliasoph 2013). However, the futurity of inflation targeting's operative functioning is, in fact, achieved by a purely procedural form of social objectivation (Salais 2016, 121ff.). Proceduralization is a type of formalization in that it disentangles a (calculative) space within which, "as long as the procedure is followed, the result obtained belongs to a sphere that is neither that which is true or just, but the unfalsifiable” (ibid., 121). That is to say, proceduralization inscribes, encases and disentangles values, rationalities and means (and ends), so that intervention can proceed free from interfering factors. Proceduralization thus also is a form of commensuration, as “commensuration as a mechanism of sense making is notable for how rigorously it simplifies information and for how thoroughly it decontextualizes knowledge” (Espeland and Sauder 2007, 17). As commensuration, it "simplifies in two ways: by making irrelevant vast amounts of information, and by imposing on what remains the same form—a shared metric” (Espeland and Sauder 2007, 17).

Making the functional relation between short-term interest rate and inflation (expectations) the operative core of inflation targeting creates a sort of procedural metric or standard for the effectiveness of monetary policy. The interaction between central banks and markets becomes "legible" (Scott 1998) to both in terms, essentially, of a covariation / relation between two (numerical) variables - that is, effectively, a standard (cf. Brunsson, Rasche, and Seidl 2012). Standards, in addition to their semantic poverty, have the additional property of enabling and encouraging a relation of “reactivity” (Espeland and Sauder 2007). One’s own actions' efficiency becomes measured in terms of (re-)actions by others (hence measured by a common standard). 
Successful coordination in terms of the standard or disentangled frame thus can become radically decoupled from actual, successful interventions in the wider context which the standard allegedly "measures", if and when the standard becomes the main or only criterion of success (Espeland and Sauder 2007; Tavory and Eliasoph 2013, 925).

In the early 1980s, the proceduralization initiated by Volcker's Monetarist Experiment was still part of a larger formalization which evaluated its operative effectiveness in terms of whether it “transmitted” into desired interaction patterns between certain (macroeconomic) aggregate variables. This means that proceduralization was, in a sense, incomplete, and much more open to interferences by the wider economic environment and its institutional rigidities. However, over the course of the decade, the Fed and other central banks vastly "improved" the formalization of their monetary policy, in the sense of closing it off to such interference. There is in particular one calculative device and instrument that proved instrumental to this process of standardization, and best illustrates the stakes involved in this process: namely, the so-called term structure of the interest rate (see Goodfriend 1998).

The credibility of monetary policy, and with it the effectiveness of inflation targeting thought to depend on it, can hardly be observed directly. Therefore, modern monetary policy requires a proxy for making the effects of its policy interventions better visible (Mann 2018, 12). Instead of a complex mess of unreliable and shifting intermediate variables, the push toward targeting expectations directly thus promised a straightforward control relation between only two variables: the short-term interest rate, and inflation expectations. The only problem was how to disentangle them from the messy context of market operations and transactions - both conceptually and operatively (Goodhart 1989, 314). Instead of measuring this effectiveness in terms of how a policy interventions is transmitted through a texture of economic aggregate indicators (with the interferences this can produce), the Fed and other central banks came to rely on the term structure of the interest rate (expressing the relationship between the interest rates or yields for the same asset at different maturities) as a calculative device which could be interpreted as making expectations legible more directly. While not the only indicator used, it is commonly the central one and typical for how monetary policy decisions are arrived at procedurally (Blinder 2004, 67).

The term structure had been used as a prism for reading the market within the Fed since at least since the 1920s. However, before the shifts I discuss in this article, this technique was used to gauge whether the Fed's measures were distorting orderly conditions in the system of financial asset prices. Rather than as a tool for capturing the (structure of) systemic expectations of inflation, it was used up to the 1980s as an instrument for sterilizing monetary policy interventions tightly connected to the Fed's concern at the time to avoid the presence of "excess", hence speculative surpluses of “idle” reserves within the financial system (see Mehrling 2011, 47ff.). 
Yield curves such as the term structure of the interest rate (typically, on government bonds such as Treasuries) thus can be used to "make legible” (Scott 1998) market expectations regarding future interest rates (and thus monetary policy stances) as well as expected inflation at various points in time. The relation between yields at different points in time, and the overall shape of the curve, can thus be "read" as a summary of market expectations relevant for monetary policy (Christophers 2017), but also investment decisions (Zaloom 2009):

“Central banks typically estimate both nominal and real yield curves for government debt instruments, and are able to extract from the combination and comparison of these what is referred to as the 'inflation term structure' or 'implied inflation curve' - in other words, the rates of inflation expected by the market at different points in time” (Christophers 2017, 66). One can therefore, "look first to the interest rate itself as a clue to underlying conditions... allowing the interest rate to speak not only about the contemporary financial order but also about the impact that current events may have on future economic conditions” (Zaloom 2009, 253). As the Fed always sets the short-end of the yield curve directly through its policy actions, the form of the curve can be read as an indicator of market expectations as to future policy measures (Christophers 2017, 65). The form of the curve can thus serve as an indicator to the credibility of monetary policy, as well as indicating the reactivity of markets to policy actions and thus their effectiveness.

As markets increasingly have come to use the yield curve as an indicator of central banks' policy stance (Christophers 2017, 66), this calculative device has become the focal point through which expectations about the future state of the economy and inflation are formed, coordinated and negotiated. This has even led some (Christophers 2017, 68) to conclude that “monetary policy fashions the economy through the yield curve; the economy reacts back on monetary policy through the yield curve". However, this game of mirrors does not involve "the economy": it only provides a disentangled metric or standard which greatly facilitates the reactivity between market and monetary policy implementation, thus giving the impression that central banks have vastly improved their ability to influence inflation as an overall, substantive economic phenomenon. However, operatively, the wider economy has been entirely evacuated from this procedure, as it is not represented in the form of any indicators within the operative procedure itself; "the economy" only enters into monetary policy externally in the form of stories about the form of the yield curve, which itself is where actual coordination takes place (see Morgan 2012, 225ff. for an account of how narratives and stories remain subordinate to the internal formalism of formal economic theories and devices). As Zaloom (2009, 253) points out, “the interest rate as a number disconnected from a specific time and place provided a powerful argument... to look first to the interest rate itself as a clue to underlying conditions. The number could be interpreted without initial reference to the specifics of time and place”.

In terms of the operative core procedures of inflation targeting, central banks do not govern the future. The term structure of the interest rate is less "an object for interpreting the contours of a 
possible future” (Zaloom 2009, 255) that would be independent of the interaction between central banks and markets, and for coordinating their actions accordingly. Instead, modern monetary policy uses "techniques of prospection with a constitutive purpose” (Mallard and Lakoff 2011, 341): while nominally regarding a future that is “external” to one’s own actions, and knowledge of which will allow one to adjust one's own course of action, in fact it serves as standard or metric which allows for the procedural simulation of policy effectiveness through the loop of reactivity it enables.

This decoupling creates a number of problems. Most problematically, the mutual (self-)observation of central banks and financial markets in terms of this narrow prism reinforces decoupling. As Alan Blinder (2004, 67ff.) has warned, central banks have begun "following the market", basing their decisions entirely on the reactive relationship between the two operational indicators, made legible in the term structure - and decoupling them from broader economic indicators that could represent the (rigid) actual structures of the economy. Through this, a joint game develops in which the Fed gains credibility and thus improves its ability to fine-tune market responses to its interventions - and conversely, so do the markets. However, both players' access to this context-reality is produced entirely by their respective reactions to one another, and the forms of legibility they develop in their interaction: in practice, the effectiveness of the procedure consists in that central banks and market actors have so internalized the pressures of reactivity that they orient their estimates of “future” values of indicators to one another’s (Braun 2015, 379). Essentially, the term structure becomes an (arbitrary) symbolic system permitting permutations of a form that can be linked through narrativizing it to "outside” states of the world (as Holmes 2014; Smart 2006 have analysed it). Importantly, however, this link is entirely at the level of narrativization (see Morgan 2001 for a general account of narrating models ) - as variation in the code system comes exclusively from within the decoupled frame and not from the transmission context it supposedly refers to. As a result, market actors come to all but ignore actual inflation rates in their decoding of central banks’ policies, focusing primarily on interest rates (Braun 2015, 379) as the variable which directly affects their operating costs. The "world in the model” (Morgan 2012) thus replaces indicators that trace transmission through (present-time) context with a future-oriented but self-referential indicator. This effectively encapsulates monetary policy implementation in a calculative space that is decoupled from that which it seeks to govern, namely the economy and its trajectory. 


\section{Conclusion: Crying wolf or the dangers of black boxing...}

In this paper, I have aimed to strike a cautionary note regarding the recent focus, in particular in economic sociology, on futurity and expectations as a distinct mode of economic (and social) coordination (e.g. Beckert 2016; Mische 2009). Monetary policy, with its claims to be governing (through) expectations and to be coordinating economic actors by the communicative construction of joint futures (Guthrie and Wright 2000; Geraats 2002), provides an instructive case for understanding the limitations of this mode of coordination. "Imagining futures” (Beckert 2016, 48ff.) thus requires formalizations and formal ways of organizing whose degree of embeddedness in the substance of social practices and structure can vary widely. As I have aimed to show, the formation of expectations may well be, especially at the surface, "shaped by the ability of humans 'to see and do things in a novel way'” (Beckert 2016, 48f.). However, “expectations in the economy are... anchored in prevailing cognitive models, which function as instruments for the construction of imagined futures” (ibid., 89).

As a result, even research that is explicitly aware of how the formation of expectations remains tied to formal devices and theories (and the loss of information that this entails), runs the risk of focusing too much on the dimensions of what I have called, following Stinchcombe (2001), the communicability gains made possible by specific formalizations, neglecting the question of their adequacy. Futurity and expectations as a mode of coordination depend on previously established typifications and categorizations (Mische 2009, 696; Beckert 2016, 51), and thus on "investment in form” (Thévenot 1984) just as much as as other “modern” forms of social organization. The danger here consists in overlooking the extensive formating and functional simplification through formalization that is necessary for "governing (through) expectations" to be possible and effective.

The case of central banking casts considerable doubt on assertions that futurity and expectation management as mode(s) of coordination are (necessarily) superior to more formal modes of organizing by allowing more flexible, discursive and reflexive consideration of the contours of a fundamentally uncertain future (see, e.g. Mische 2009, 697; Beckert 2016, 51ff.). As I have shown, modern monetary policy’s management of expectations depends heavily on extensive processes of standardization, commensuration and quantification that provide the durable frames within which expectations can coordinate - but at the cost of undermining the openness to revision of its underlying categorizations, measurements and equivalences (see Thévenot 2009, 806 for an argument as to why closure and standardization go hand in hand).

It may thus well be true that "central banks and forecasting institutes achieve the copresence of various evaluative schemes through intensive discursive exchanges within the epistemic community and 'the economy”” (Beckert 2016, 260; see also Holmes 2009, 392). But, as I have shown, the (apparent) communicative openness of modern monetary policy is made possible precisely by the functional simplification of its operative core to formal procedures which are 
closed off to the very semantic richness and openness that the communicative surface practices of central banks make reference to (see Holmes 2014).

The more cautious tales told by (former) practitioners that have escaped everyday operative constraints provide some guidance as to the dangers of overlooking the modes of formalization that underlie the more communicative dynamics of governing by expectations and futurity. As Holmes is forced to admit, among both practitioners and economists, "there is no consensus on why the framework is successful, why and how expectations become anchored by virtue of these targeting protocols” (Holmes 2009, 403). Even in purely technical terms, the term structure of the interest rate is, as a device for empirically predicting future interest rates, an "abject failure" in the words of former Fed governor Alan Blinder (Blinder 2004, 74ff.).

None of this is particularly surprising if we bear in mind that the formalization and proceduralization of the domain in question (Thévenot 1984; Kallinikos 2004; Habermas 1969) are a precondition for being able to commensurate multiple (and heterogeneous) expectations and thus arrive at a definite and efficacious course of action (or policy implementation) for pursuing a “common good”. Formalization and proceduralization are, however, if not the natural enemy, so at least a natural source of pathologies for any mode of coordination and governing. In particular, the standardization and formality involved make it difficult for "an abstraction system... to have a trajectory of improvement so that it can track changes in the world, increase its scope, and correct its errors” (Stinchcombe 2001, 10). Proceduralization of monetary policy has created an intertemporal standard by which reactivity can be organized.

As long as monetary policy functions within this standard and the frame it establishes, its adequacy and effectiveness are constantly reaffirmed. However, as the 2008-09 financial crisis has demonstrated, this formalization has radically curtailed what the Fed can "see"- or, more precisely, what it can operatively and procedurally process and tackle. From the perspective developed here, it is thus not so much "culture, cognition, and framing” (Fligstein, Stuart Brundage, and Schultz 2017) that account for the Fed's failure to notice the financial fragilities that led to the crisis - but rather the semantic decoupling of its operative procedures from the formal representations of the economic system which, of course, it continued to produce and debate.

The “interactive nature of the 'signaling process' between the central bank and those economic actors whose activities propel the transmission” (Braun 2015, 369) thus appears to be part of the problem rather than a solution to it: rather than improve the adequacy of governing through expectations to the "situations" in which agents operated (Stark 2009, 14ff.), the closure through formalization that made this signaling process possible meant that monetary policy became operatively less responsive or accountable to situated knowledges, mimicking rather than achieving adequacy to the substance of the economic processes to be governed. Proceduralization, in this as in other cases, entails that the immediate reactivity and appropriateness to the other's reaction 
overrides the longer-term, "projective” significance of what is being done (see Tavory and Eliasoph 2013, 924). 


\section{References:}

Abolafia, M. Y. 2010. "Narrative Construction as Sensemaking: How a Central Bank Thinks.” Organization Studies 31 (3): 349-67. https://doi.org/10.1177/0170840609357380.

Axilrod, Stephen H., and David E. Lindsey. 1981. "Federal Reserve System Implementation of Monetary Policy: Analytical Foundations of the New Approach.” American Economic Association 71 (2): 246-52.

Backhouse, Roger. 1995. Interpreting Macroeconomics: Explorations in the History of Macroeconomic Thought. London ; New York: Routledge.

Beckert, Jens. 2016. Imagined Futures: Fictional Expectations and Capitalist Dynamics. Cambridge, Massachusetts: Harvard University Press.

Bernanke, Ben. 2004. “The Great Moderation.” Remarks by the Governor of the Federal Reserve presented at the Meetings of the Eastern Economic Association, Washington D.C., February. http://www.federalreserve.gov/boarddocs/speeches/2004/20040220/.

Bernanke, Ben, and Frederic S. Mishkin. 1997. "Inflation Targeting: A New Framework for Monetary Policy?” 5893. NBER Working Paper. Cambridge Mass.: National Bureau of Economic Research.

Bernanke, Ben, and Michael Woodford, eds. 2006. The Inflation-Targeting Debate. Paperback ed. National Bureau of Economic Research Studies in Business Cycles 32. Chicago, Ill.: Univ. of Chicago Press.

Bindseil, Ulrich. 2004. Monetary Policy Implementation. Oxford; New York: Oxford University Press.

Blanchard, Olivier. 2008. "Neoclassical Synthesis.” In The New Palgrave Dictionary of Economics, edited by Steven N. Durlauf and Lawrence E. Blume, 2nd ed., 896-99. Basingstoke: Nature Publishing Group. http://www.dictionaryofeconomics.com/article?id=pde2008_N000041.

Blinder, Alan. 2004. The Quiet Revolution : Central Banking Goes Modern. New Haven: Yale University Press.

Bowdler, C., and A. Radia. 2012. "Unconventional Monetary Policy: The Assessment.” Oxford Review of Economic Policy 28 (4): 603-21. https://doi.org/10.1093/oxrep/grs037.

Braun, Benjamin. 2015. “Governing the Future: The European Central Bank’s Expectation Management during the Great Moderation.” Economy and Society 44 (3): 367-91. https://doi.org/10.1080/03085147.2015.1049447. . 2016. "Speaking to the People? Money, Trust, and Central Bank Legitimacy in the Age of Quantitative Easing.” Review of International Political Economy 23 (6): 1064-92. https://doi.org/10.1080/09692290.2016.1252415.

Brunsson, N., A. Rasche, and D. Seidl. 2012. "The Dynamics of Standardization: Three Perspectives on Standards in Organization Studies.” Organization Studies 33 (5-6): 613-32. https://doi.org/10.1177/0170840612450120.

Callon, Michel, and John Law. 1982. "On Interests and Their Transformation: Enrolment and Counter-Enrolment.” Social Studies of Science 12 (4): 615-25. https://doi.org/10.1177/030631282012004006.

Callon, Michel, and Fabian Muniesa. 2005. "Peripheral Vision: Economic Markets as Calculative Collective Devices.” Organization Studies 26 (8): 1229-50. https://doi.org/10.1177/0170840605056393.

Carruthers, Bruce G., and Sarah Babb. 1996. "The Color of Money and the Nature of Value: Greenbacks and Gold in Postbellum America.” American Journal of Sociology 101 (6): 1556-91.

Cesarano, Filippo. 1983. “The Rational Expectations Hypothesis in Retrospect.” The American Economic Review 73 (1): 198-203.

Christophers, Brett. 2017. “The Performativity of the Yield Curve.” Journal of Cultural Economy 10 (1): 63-80. https://doi.org/10.1080/17530350.2016.1236031.

Cukierman, Alex, and Allan H. Meltzer. 1986. "A Theory of Ambiguity, Credibility, and Inflation under Discretion and Asymmetric Information.” Econometrica 54 (5): 1099. https://doi.org/ $10.2307 / 1912324$. 
Darity, William A. Jr., and Warren Young. 1995. “IS-LM: An Inquest.” History of Political Economy 27 (1): 1-41.

Desrosières, Alain. 2013. Pour une sociologie historique de la quantification L'Argument statistique I. Paris: Presses des Mines. http://books.openedition.org/pressesmines/901.

Diaz-Bone, Rainer. 2016. “Convention Theory, Classification and Quantification.” Historical Social Research / Historische Sozialforschung 41 (2): 48-71.

Dimand, Robert W. 2007. "Keynes, IS-LM, and the Marshallian Tradition.” History of Political Economy 39 (1): 81-95. https://doi.org/10.1215/00182702-2006-024.

Espeland, Wendy Nelson, and Michael Sauder. 2007. "Rankings and Reactivity: How Public Measures Recreate Social Worlds.” American Journal of Sociology 113 (1): 1-40.

Feinman, Joshua, and William Poole. 1989. "Federal Reserve Policymaking: An Overview and Analysis of the Policy Process: A Comment.” Carnegie-Rochester Conference Series on Public Policy 30 (March): 63-74. https://doi.org/10.1016/0167-2231(89)90020-1.

Fernández-Albertos, José. 2015. “The Politics of Central Bank Independence.” Annual Review of Political Science 18 (1): 217-37. https://doi.org/10.1146/annurev-polisci-071112-221121.

Fligstein, Neil, Jonah Stuart Brundage, and Michael Schultz. 2017. "Seeing Like the Fed: Culture, Cognition, and Framing in the Failure to Anticipate the Financial Crisis of 2008." American Sociological Review 82 (5): 879-909. https://doi.org/10.1177/0003122417728240.

Friedman, Benjamin. 2002. "The Use and Meaning of Words in Central Banking: Inflation Targeting, Credibility, and Transparency.” w8972. Cambridge, MA: National Bureau of Economic Research. https://doi.org/10.3386/w8972.

Friedman, Milton. 1968. “The Role of Monetary Policy.” The American Economic Review 58 (1): $1-17$.

Geraats, Petra M. 2002. “Central Bank Transparency*.” The Economic Journal 112 (483): F532-65. https://doi.org/10.1111/1468-0297.00082.

Glasner, David. 1992. "The Real-Bills Doctrine in the Light of the Law of Reflux.” History of Political Economy 24 (4): 867-94.

Golub, Stephen, Ayse Kaya, and Michael Reay. 2014. "What Were They Thinking? The Federal Reserve in the Run-up to the 2008 Financial Crisis.” Review of International Political Economy, July, 1-36. https://doi.org/10.1080/09692290.2014.932829.

Goodfriend, Marvin. 1998. "Using the Term Structure of Interest Rates for Monetary Policy.” Federal Reserve Bank of Richmond Economic Quarterly 84 (3): 13-28. . 2007. "How the World Achieved Consensus on Monetary Policy." 13580. NBER Working Paper Series. Cambridge, MA: National Bureau of Economic Research.

Goodhart, Charles A. 1989. "The Conduct of Monetary Policy.” The Economic Journal 99 (396): 293-346.

Guthrie, Graeme, and Julian Wright. 2000. “Open Mouth Operations.” Journal of Monetary Economics 46 (2): 489-516. https://doi.org/10.1016/S0304-3932(00)00035-0.

Habermas, Jürgen. 1969. Technik Und Wissenschaft Als “Ideologie.” Edition Suhrkamp. Frankfurt am Main: Suhrkamp Verlag.

1973. Erkenntnis Und Interesse. Frankfurt am Main: Suhrkamp Verlag.

Hacking, Ian. 1983. Representing and Intervening: Introductory Topics in the Philosophy of Natural Science. Cambridge [Cambridgeshire] ; New York: Cambridge University Press.

Hall, Rodney. 2008. Central Banking as Global Governance : Constructing Financial Credibility. Cambridge UK ;;New York: Cambridge University Press.

Hasselbladh, H., and Jannis Kallinikos. 2000. "The Project of Rationalization: A Critique and Reappraisal of Neo-Institutionalism in Organization Studies.” Organization Studies 21 (4): 697-720. https://doi.org/10.1177/0170840600214002.

Hicks, John. 1937. “Mr. Keynes and the 'Classics'; A Suggested Interpretation.” Econometrica 5 (2): $147-59$.

Holmes, Douglas R. 2009. “Economy of Words.” Cultural Anthropology 24 (3): 381-419. https://doi.org/10.1111/j.1548-1360.2009.01034.x. . 2014. Economy of Words: Communicative Imperatives in Central Banks. Chicago ; London: The University of Chicago Press. 
Hoover, Kevin D. 2001. The Methodology of Empirical Macroeconomics. Cambridge, UK ; New York, NY: Cambridge University Press.

Kallinikos, Jannis. 2004. “The Social Foundations of the Bureaucratic Order.” Organization 11 (1): 13-36. https://doi.org/10.1177/1350508404039657.

. 2006. The Consequences of Information: Institutional Implications of Technological Change. Cheltenham: Edward Elgar.

. 2014. Governing through Technology: Information Artefacts and Social Practice. Place of publication not identified: Palgrave Macmillan.

Kallinikos, Jannis, Hans Hasselbladh, and Attila Marton. 2013. "Governing Social Practice: Technology and Institutional Change.” Theory and Society 42 (4): 395-421. https://doi.org/10.1007/s11186-013-9195-y.

Kirman, Alan P. 1992. “Whom or What Does the Representative Individual Represent?” Journal of Economic Perspectives 6 (2): 117-36.

Konings, Martijn. 2011. The Development of American Finance. New York: Cambridge University Press.

Krippner, Greta. 2011. Capitalizing on Crisis : The Political Origins of the Rise of Finance. Cambridge Mass.: Harvard University Press.

Latour, Bruno. 1990. “Drawing Things Together.” In Representation in Scientific Practice, edited by Michael Lynch and Steve Woolgar. Cambridge Mass.: MIT Press.

Lucas, Robert E. 1972. "Expectations and the Neutrality of Money.” Journal of Economic Theory 4 (2): 103-24. https://doi.org/10.1016/0022-0531(72)90142-1.

Lucas, Robert E. 1996. “Nobel Lecture: Monetary Neutrality.” Journal of Political Economy 104 (4): 661-82.

MacKenzie, Donald. 2005. “Opening the Black Boxes of Global Finance.” Review of International Political Economy 12 (4): 555-76. 2006. An Engine, Not a Camera : How Financial Models Shape Markets. Cambridge Mass.: MIT Press. . 2017. "A Material Political Economy: Automated Trading Desk and Price Prediction in High-Frequency Trading.” Social Studies of Science 47 (2): 172-94. https://doi.org/10.1177/0306312716676900.

Mallard, Grégoire. 2017. "From Europe’s Past to the Middle East’s Future: The Constitutive Purpose of Forward Analogies in International Security.” American Journal of Cultural Sociology, September. https://doi.org/10.1057/s41290-017-0049-3.

Mallard, Grégoire, and Andrew Lakoff. 2011. "How Claims to Know the Future Are Used to Understand the Present: Techniques of Prospection in the Field of National Security.” In Social Knowledge in the Making, edited by Charles Camic, Neil Gross, and Michèle Lamont, 339-78. Chicago: The University of Chicago Press.

Mann, Geoff. 2018. "Equation and Adequation: The World Traced by the Phillips Curve: Equation and Adequation.” Antipode 50 (1): 1-28. https://doi.org/10.1111/anti.12321.

McNamara, Kathleen. 2002. "Rational Fictions: Central Bank Independence and the Social Logic of Delegation.” West European Politics 25 (1): 47-76. https://doi.org/10.1080/713601585.

Mehrling, Perry. 2011. The New Lombard Street : How the Fed Became the Dealer of Last Resort. Princeton, N.J.: Princeton University Press.

Meltzer, Allan H. 1991. “The Fed at Seventy Five.” In Monetary Policy on the 75th Anniversary of the Federal Reserve System, edited by Michael T. Belongia, 3-65. Dordrecht: Springer Netherlands.

Meyer, John W., and Brian Rowan. 1977. "Institutionalized Organizations: Formal Structure as Myth and Ceremony.” The American Journal of Sociology 83 (2): 340-63.

Mirowski, Philip. 1989. More Heat than Light : Economics as Social Physics, Physics as Nature's Economics. Cambridge; New York: Cambridge University Press.

2002. Machine Dreams : Economics Becomes a Cyborg Science. Cambridge; New York: Cambridge University Press.

Mische, Ann. 2009. "Projects and Possibilities: Researching Futures in Action.” Sociological Forum 24 (3): 694-704. https://doi.org/10.1111/j.1573-7861.2009.01127.x. 
Morgan, Mary S. 2001. "Models, Stories and the Economic World.” Journal of Economic Methodology 8 (3): 361-84. https://doi.org/10.1080/13501780110078972.

. 2012. The World in the Model: How Economists Work and Think. Cambridge ; New York: Cambridge University Press.

Morris, Stephen, and Hyun Song Shin. 2008. “Coordinating Expectations in Monetary Policy.” In Central Banks as Economic Institutions, edited by Jean-Philippe Touffut. Cheltenham UK ;;Northampton MA: Edward Elgar.

Offe, Claus. 2006. Strukturprobleme Des Kapitalistischen Staates : Aufsätze Zur Politischen Soziologie. Veränd. Neuausg. : Frankfurt/Main ;;New York: Campus.

Orphanides, Athanasios. 2002. "Monetary-Policy Rules and the Great Inflation.” The American Economic Review 92 (2): 115-20. . 2003. “The Quest for Prosperity without Inflation.” Journal of Monetary Economics 50 (3): 633-63. https://doi.org/10.1016/S0304-3932(03)00028-X.

Poole, William. 1970. "Optimal Choice of Monetary Policy Instruments in a Simple Stochastic Macro Model.” The Quarterly Journal of Economics 84 (2): 197-216.

Power, Michael. 1997. The Audit Society: Rituals of Verification. Oxford, [England] ; New York: Oxford University Press. . 2007. Organized Uncertainty: Designing a World of Risk Management. Oxford ;;New York: Oxford University Press.

Rose, Nikolas. 1993. “Government, Authority and Expertise in Advanced Liberalism.” Economy and Society 22 (3): 283-99. https://doi.org/10.1080/03085149300000019.

Rose, Nikolas, and Peter Miller. 1992. "Political Power beyond the State: Problematics of Government.” The British Journal of Sociology 43 (2): 173-205.

Rosenblum, Harvey, and Steven Strongin. 1983. "Interest Rate Volatility in Historical Perspective.” Economic Perspectives 7 (1): 10-19.

Salais, Robert. 2012. "Quantification and the Economics of Convention.” Historical Social Research / Historische Sozialforschung 37 (4): 55-63. . 2016. "Quantification and Objectivity. From Statistical Conventions to Social Conventions.” Historical Social Research / Historische Sozialforschung 41 (2): 118-34. https://doi.org/10.12759/hsr.41.2016.2.118-134.

Scott, James C. 1998. Seeing like a State: How Certain Schemes to Improve the Human Condition Have Failed. Yale Agrarian Studies. New Haven: Yale University Press.

Smart, Graham. 2006. Writing the Economy: Activity, Genre, and Technology in the World of Banking. Studies in Language and Communication. London ; Oakville, CT: Equinox.

Stark, David. 2009. The Sense of Dissonance: Accounts of Worth in Economic Life. Princeton: Princeton University Press.

Stinchcombe, Arthur L. 2001. When Formality Works: Authority and Abstraction in Law and Organizations. Chicago: University of Chicago Press.

Suchman, L. 2000. “Organizing Alignment: A Case of Bridge-Building.” Organization 7 (2): 31127. https://doi.org/10.1177/135050840072007.

Tavory, Iddo, and Nina Eliasoph. 2013. "Coordinating Futures: Toward a Theory of Anticipation.” American Journal of Sociology 118 (4): 908-42. https://doi.org/10.1086/668646.

Thévenot, Laurent. 1984. "Rules and Implements: Investment in Forms.” Social Science Information 23 (1): 1-45. https://doi.org/10.1177/053901884023001001. . 2001a. "Pragmatic Regimes Governing The Engagement With The World.” In The Practice Turn in Contemporary Theory, edited by Theodore R. Schatzki, Karin Knorr Cetina, and Eike von Savigny, 56-73. London: Routledge.

. 2001b. "Organized Complexity: Conventions of Coordination and the Composition of Economic Arrangements.” European Journal of Social Theory 4 (4): 405-25. https://doi.org/ $10.1177 / 13684310122225235$.

. 2009. "Postscript to the Special Issue: Governing Life by Standards: A View from Engagements.” Edited by Alberto Cambrosio, Peter Keating, Thomas Schlich, and George Weisz. Social Studies of Science 39 (5): 793-813. https://doi.org/10.1177/0306312709338767. 
Weick, Karl E., Kathleen M. Sutcliffe, and David Obstfeld. 2005. "Organizing and the Process of Sensemaking.” Organization Science 16 (July): 409-21.

Woodford, Michael. 2003. Interest and Prices Foundations of a Theory of Monetary Policy. Princeton (N.J.); Oxford: Princeton University Press.

Young, Warren, and Ben Zion Zilberfarb. 2000. IS-LM and Modern Macroeconomics. Dordrecht: Springer Netherlands. http://dx.doi.org/10.1007/978-94-010-0644-6.

Zaloom, C. 2009. "How to Read the Future: The Yield Curve, Affect, and Financial Prediction." Public Culture 21 (2): 245-68. https://doi.org/10.1215/08992363-2008-028. 